\title{
Wintertime particulate pollution episodes in an urban valley of the Western US: a case study
}

\author{
L.-W. A. Chen ${ }^{1,2}$, J. G. Watson ${ }^{1,2}$, J. C. Chow ${ }^{1,2}$, M. C. Green ${ }^{1}$, D. Inouye ${ }^{3}$, and K. Dick ${ }^{3}$ \\ ${ }^{1}$ Division of Atmospheric Sciences, Desert Research Institute, 2215 Raggio Parkway, Reno, NV 89512, USA \\ ${ }^{2}$ State Key Laboratory of Loess and Quaternary Geology, Institute of Earth Environment, Chinese Academy of Sciences, \\ Xi'an, China \\ ${ }^{3}$ Washoe County District Health Department Air Quality Management Division, Reno, NV, USA
}

Correspondence to: L.-W. A. Chen (antony.chen@dri.edu)

Received: 18 April 2012 - Published in Atmos. Chem. Phys. Discuss.: 26 June 2012

Revised: 24 September 2012 - Accepted: 7 October 2012 - Published: 2 November 2012

\begin{abstract}
This study investigates the causes of elevated $\mathrm{PM}_{2.5}$ episodes and potential exceedences of the US National Ambient Air Quality Standards (NAAQS) in Truckee Meadows, Nevada, an urban valley of the Western US, during winter 2009/2010, an unusually cold and snowy winter. Continuous $\mathrm{PM}_{2.5}$ mass and time-integrated chemical speciation data were acquired from a central valley monitoring site, along with meteorological measurements from nearby sites. All nine days with $\mathrm{PM}_{2.5}>35 \mu \mathrm{g} \mathrm{m}^{-3}$ showed 24-h average temperature inversion of $1.5-4.5^{\circ} \mathrm{C}$ and snow cover of $8-18 \mathrm{~cm}$. Stagnant atmospheric conditions limited wind ventilation while highly reflective snow cover reduced daytime surface heating creating persistent inversion. Elevated ammonium nitrate $\left(\mathrm{NH}_{4} \mathrm{NO}_{3}\right)$ and water associated with it are found to be main reasons for the $\mathrm{PM}_{2.5}$ exceedances. An effective-variance chemical mass balance (EV-CMB) receptor model using locally-derived geological profiles and inorganic/organic markers confirmed secondary $\mathrm{NH}_{4} \mathrm{NO}_{3}(27-$ $37 \%$ ), residential wood combustion (RWC; 11-51\%), and diesel engine exhaust (7-22\%) as the dominant $\mathrm{PM}_{2.5}$ contributors. Paved road dust and de-icing materials were minor, but detectable contributors. RWC is a more important source than diesel for organic carbon (OC), but vice versa for elemental carbon (EC). A majority of secondary $\mathrm{NH}_{4} \mathrm{NO}_{3}$ is also attributed to RWC and diesel engines (including snow removal equipment) through oxides of nitrogen $\left(\mathrm{NO}_{\mathrm{x}}\right)$ emissions from these sources. Findings from this study may apply to similar situations experienced by other urban valleys.
\end{abstract}

\section{Introduction}

The Truckee Meadows is a mountain valley in Northern Nevada of the US with the Sierra Nevadas to its west and the Great Basin to its east. The area of the valley floor is $\sim 25 \mathrm{~km}^{2}$, containing downtowns of the cities of Reno and Sparks with a population of $\sim 200000$ (2010 census). It is distant from major metropolitan areas by at least $200 \mathrm{~km}$. Similar urban valleys are common in the Western Cordillera region, including Salt Lake City, Utah, BoiseNampa, Idaho, Missoula, Montana, and Kelowna, British Columbia (Canada). Air quality in such valleys is determined by the interaction between synoptic winds and local thermal circulation (Fernando, 2010). Under stable conditions, pollutants released from the valley floor tend to be confined by surrounding mountain ranges leading to elevated pollution episodes.

Particulate matter $2.5\left(\mathrm{PM}_{2.5}\right.$, airborne particles with aerodynamic diameter equal or less than $2.5 \mu \mathrm{m}$ ) is a criteria air pollutant regulated by the US Environmental Protection Agency (USEPA) for its adverse effects on public health, visibility, and environment (USEPA, 2004). PM 2.5 episodes often show patterns (e.g., chemical composition and seasonality) related to region-specific meteorology and sources (Chu, 2004; Tai et al., 2010). Compliance monitoring for $\mathrm{PM}_{2.5}$ in the Truckee Meadows (Mendoza and Inouye, 2011) showed that most of the high values occurred during winter, with some excursions during late summer and fall when smoke from regional wildfires was a contributor. LingBarnes (2010) estimates that most primary $\mathrm{PM}_{2.5}$ emissions 
in the Truckee Meadows are from area (non-point) sources associated with wintertime residential heating. Other important sources include motor vehicle engine exhaust and fugitive dust.

Although Mendoza and Inouye (2011) have demonstrated attainment of $\mathrm{PM}_{2.5}$ National Ambient Air Quality Standards (NAAQS) of $15 \mu \mathrm{g} \mathrm{m}^{-3}$ annual arithmetic mean, averaged over three years, and $35 \mu \mathrm{g} \mathrm{m}^{-3}$ for the 98th percentile of 24-h averages, averaged over three years (Bachmann, 2007; Chow et al., 2007b), in the Truckee Meadows since 2001, several 24-h $\mathrm{PM}_{2.5}$ concentrations exceeding $35 \mu \mathrm{g} \mathrm{m}^{-3}$ were observed from 2008 to 2010 . Considering also that USEPA (2012) has recently proposed reducing the annual NAAQS to $12-13 \mu \mathrm{g} \mathrm{m}^{-3}$, these high episodes raise concerns of potential NAAQS non-attainment in the future.

This study investigates interactions between meteorology and emissions that lead to wintertime $\mathrm{PM}_{2.5}$ episodes in the Truckee Meadows valley. The analysis is based on regulatory monitoring data and additional measurements on archived samples that facilitate source apportionment using a chemical mass balance (CMB) approach. Findings from this study provide information for developing strategies to reduce $\mathrm{PM}_{2.5}$ levels in this and similar urban valleys.

\section{Ambient monitoring data collection and analysis}

The main $\mathrm{PM}_{2.5}$ monitoring site in Reno (RENO_C: $39.525079^{\circ} \mathrm{N},-119.807723^{\circ} \mathrm{W}, 1371 \mathrm{~m}$ a.m.s.l.) is located in a residential/commercial area south of the Truckee River, $\sim 2 \mathrm{~km}$ west of the I-580 north/south freeway and $\sim 1 \mathrm{~km}$ south of the I-80 east/west freeway. A Mexican restaurant is located $\sim 20 \mathrm{~m}$ east of the station. As part of the USEPA Speciation Trends Network (STN), $\mathrm{PM}_{2.5}$ filters have been acquired at RENO_C every 3rd day with speciation samplers (Met One SASS + URG 3000N Carbon Sampler) for chemical characterization (Chow et al., 2010; Flanagan et al., 2006). Additional $\mathrm{PM}_{2.5}$ and $\mathrm{PM}_{10}$ filter samples are taken with Federal Reference Method (FRM) samplers for gravimetric analysis of mass concentrations. Hourly average $\mathrm{PM}_{2.5}$ and oxides of nitrogen $\left(\mathrm{NO}_{\mathrm{x}}\right)$ are also measured by a beta attenuation monitor (BAM; MetOne E-BAM; Grants Pass, OR) and a chemiluminescent analyzer (42C, Thermo Environmental Instruments, Franklin, MA), respectively. The sampling probes are situated $\sim 4 \mathrm{~m}$ above ground level and $\sim 1 \mathrm{~m}$ above the rooftop of the shelter. For this study, data for the December 2008-January 2009 and December 2009-January 2010 were retrieved from USEPA's Air Quality System database (AQS; http://www.epa.gov/ttn/ airs/airsaqs/index.htm). Concurrent meteorological observations were obtained from stations on the valley floor and at higher elevations, as shown in Fig. 1.

Based on the FRM measurements, there were four 24-h $\mathrm{PM}_{2.5}$ samples exceeding $35 \mu \mathrm{g} \mathrm{m}^{-3}$ out of 20 measurements at the RENO_C site during December 2009 and Jan-

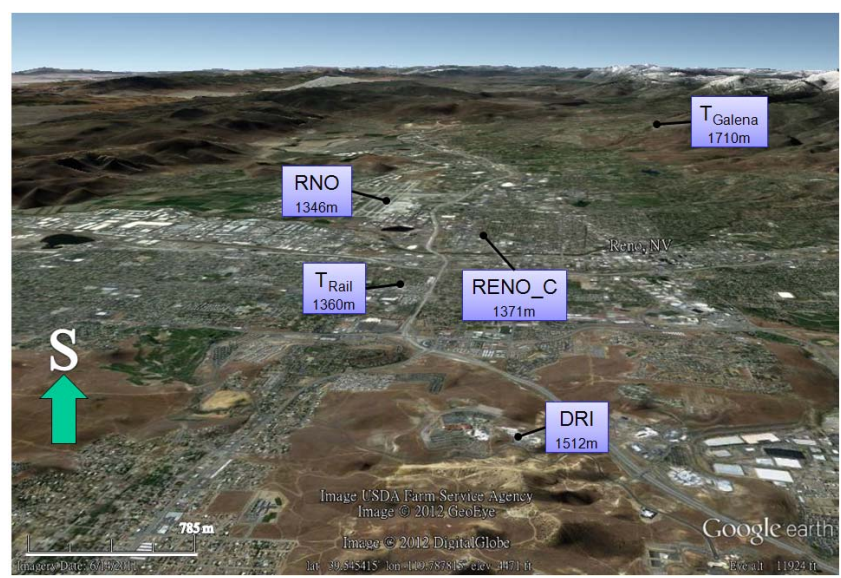

Fig. 1. Topography of the Truckee Meadows valley and locations/elevations of $\mathrm{PM}_{2.5}$ monitoring site (RENO_C), valley-floor weather station (Reno Rail Yard, $T_{\text {Rail }}$ ), elevated weather station (Galena, $T_{\text {Galena }}$ ), Reno-Tahoe International Airport (RNO), and the Desert Research Institute (DRI).

uary 2010 (i.e., 9, 15, 18 December 2009, and 5 January 2010). Daily averaged BAM data reported five additional $\mathrm{PM}_{2.5}$ exceedances (i.e., 10, 11, 14, 19, and 20 December 2009) during the period. The December 2009-January 2010 average FRM $\mathrm{PM}_{2.5}$ mass concentration was $17.9 \mu \mathrm{g} \mathrm{m}^{-3}$, $\sim 45 \%$ higher than the December 2008-January 2009 average $\left(12.3 \mu \mathrm{g} \mathrm{m}^{-3}\right)$. $\mathrm{PM}_{2.5}$ mass from the BAM and the speciation samplers showed good agreement with the FRM mass $\left(r^{2}>0.95\right.$ and average differences within $\left.\pm 7 \%\right)$ (Watson et al., 2011).

\subsection{Meteorological characteristics of $\mathbf{P M}_{2.5}$ episodes}

Temperature inversions often reflect calm winds and low vertical dispersion that enhance accumulation of pollutants released from the surface. Valley-floor and elevated meteorological observations (Fig. 1) were used to characterize the strength of inversions in the Truckee Meadows area. The Reno Rail Yard site $\left(39.5391^{\circ} \mathrm{N} 119.78605^{\circ} \mathrm{W}\right)$ is on the valley floor at an elevation of $1360 \mathrm{~m}$ mean sea level (m.s.l.), $\sim 1.3 \mathrm{~km}$ northeast of RENO_C, while the Galena Remote Automated Weather Station (RAWS) site $\left(39.3794^{\circ} \mathrm{N}\right.$ $119.8319^{\circ} \mathrm{W}$ ) is at an elevation of $1710 \mathrm{~mm}$.s.l., generally upwind of the Truckee Meadows, and at the top of the atmospheric boundary layer.

Good relationships were found between $\mathrm{PM}_{2.5}$ mass at the RENO_C site and vertical temperature differences. For winter 2009/2010, Fig. 2a shows that there were three periods (i.e., 8-11 December 2009; 14-20 December 2009; and 3-6 January 2010) of persistent, multi-day inversions with maximum inversion strengths $\left(\Delta T=T_{\text {Galena }}-T_{\text {Rail }}\right)>5^{\circ} \mathrm{C}$ and minimum $\Delta T>-2{ }^{\circ} \mathrm{C}$. During these periods, $\Delta T$ peaked at or just before midday. As surface heating increased in the afternoon, the inversion coupled to layers aloft near 16:00 local 


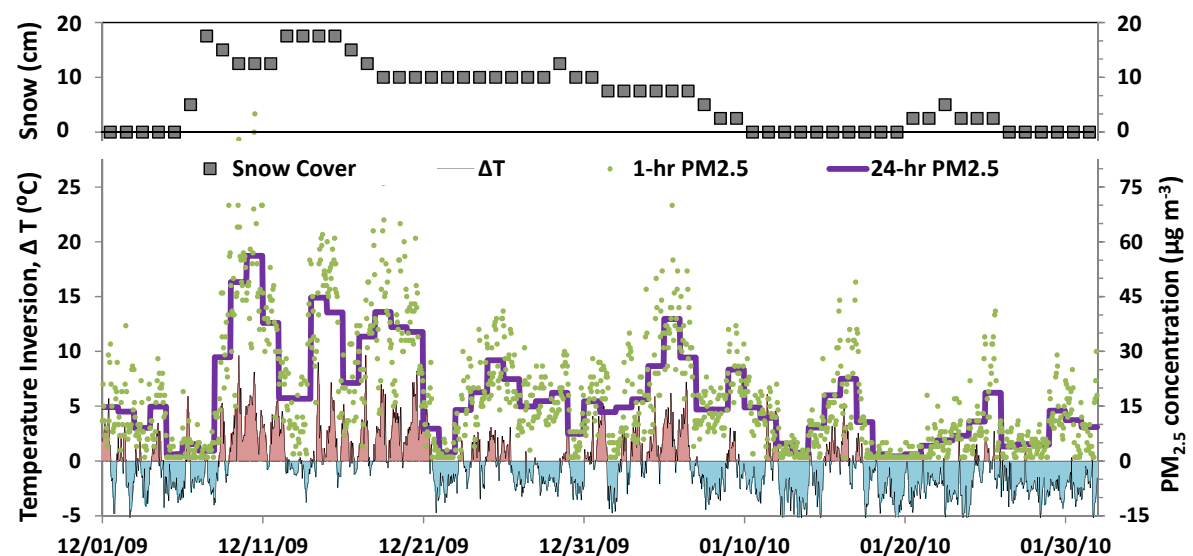

(a)

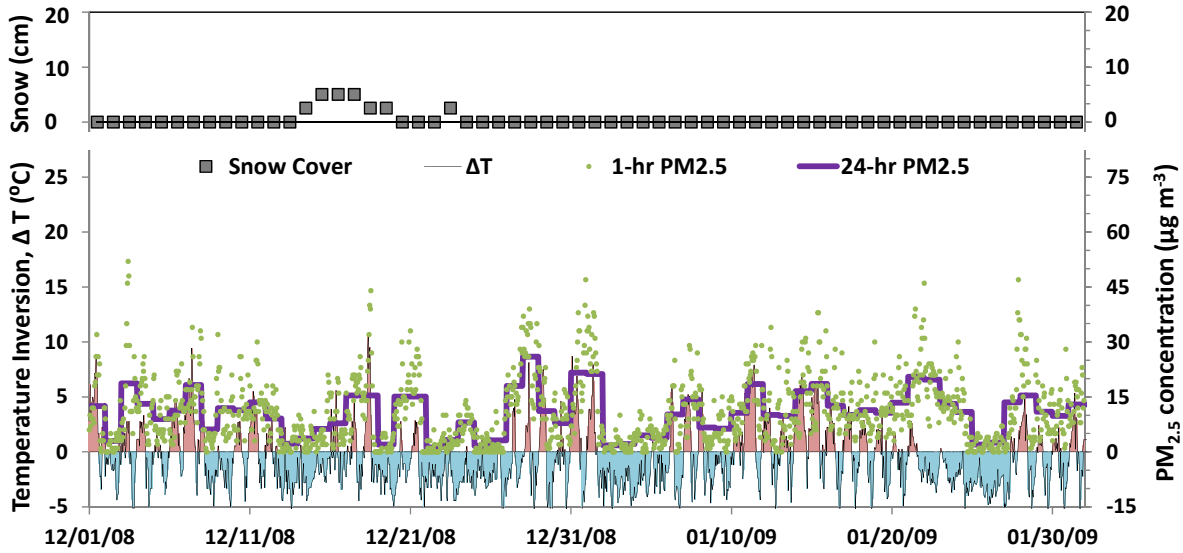

(b)

Fig. 2. Snow cover (daily), temperature inversion ( $\left.\Delta T=T_{\mathrm{Galena}}-T_{\mathrm{Rail}}\right)$, and corresponding $\mathrm{PM}_{2.5}$ mass concentrations by beta attenuation monitor (BAM) during: (a) December 2009-January 2010, and (b) December 2008-January 2009. $\Delta T>0$ (i.e., with inversion) and $\Delta T<0$ are marked by red and blue, respectively.

standard time (LST), but re-instated itself soon after sunset. The highest $\mathrm{PM}_{2.5}$ concentrations, including all 24-h exceedances, occurred near the middle of each inversion period. For other times of the winter, inversions were weak and short-lived, typically lasting no more than several hours. The winter also experienced a few snow storms during which no inversions occurred throughout a day.

There were neither extended periods of strong inversions nor $\mathrm{PM}_{2.5}$ exceedances during winter 2008/2009 (Fig. 2b). Daily average $\Delta T$ is positively correlated with 24-h $\mathrm{PM}_{2.5}$ measured by BAM with $r^{2}$ of 0.785 and 0.420 for winter $2009 / 2010$ and winter 2008/2009, respectively. Inversions have been confirmed by Silcox et al. (2012) to strongly influence $\mathrm{PM}_{2.5}$ concentration in the Salt Lake City valley, though in that study inversion (or stability) was measured through heat deficit, the energy required to dry adiabatically mix a layer.

December 2009 was the sixth coldest and fifth snowiest December $(39.6 \mathrm{~cm}$ snowfall) recorded since 1931 at the
Reno-Tahoe International Airport (RNO, see Fig. 1). Snowfall was low to moderate for the other three months (1.3$15.0 \mathrm{~cm}$; December 2008, January 2009, and January 2010). Highly reflective and melting snow cover reduces daytime surface heating, which allows the formation of persistent inversions throughout the day under stable synoptic conditions. Forty-eight out of 124 days in the two winter periods recorded snow cover of $\geq 2.5 \mathrm{~cm}$ at RNO with an average daily $\Delta T$ of $0.1 \pm 3.6^{\circ} \mathrm{C}$, which is significantly higher ( $p=0.005)$ than the average daily $\Delta T$ of $-1.6 \pm 2.9^{\circ} \mathrm{C}$ for the 76 days without snow cover. High $\Delta T$ can occur on days without snow cover, but heating in the afternoon on those days is usually strong enough to break the inversion completely, avoiding day-to-day accumulation. This was the case for most of winter 2008/2009 as shown in Fig. 2b. Snow cover also increased relative humidity (RH), as RH averaged $78 \%$ on snow-cover days and $66 \%$ on no-snow-cover days.

Figure 3 compares BAM $\mathrm{PM}_{2.5}$ in both winters as a function of $\Delta T$ and snow cover. All nine days with 


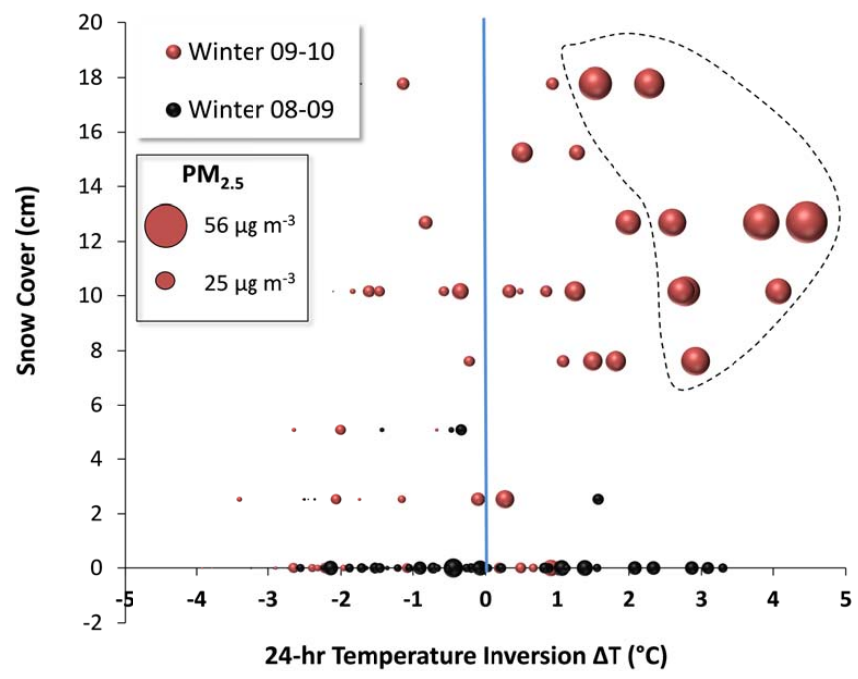

Fig. 3. Average 24-h $\mathrm{PM}_{2.5}$ mass concentration (bubble diameter) by beta attenuation monitor (BAM) as a function of temperature inversion $\left(\Delta T=T_{\text {Galena }}-T_{\text {Rail }}\right)$ and snow cover. The largest bubble corresponds to $56.1 \mu \mathrm{g} \mathrm{m}^{-3}$ of $\mathrm{PM}_{2.5}$. The dashed circle encloses all nine days that exceeded the USEPA 24-h $\mathrm{PM}_{2.5}$ National Ambient Air Quality Standard (NAAQS) of $35 \mu \mathrm{g} \mathrm{m}^{-3}$.

$\mathrm{PM}_{2.5}>35 \mu \mathrm{g} \mathrm{m}^{-3}$ experienced $24-\mathrm{h} \Delta T$ of 1.5 to $4.5^{\circ} \mathrm{C}$ and snow cover of $8-18 \mathrm{~cm}$. There had been much less snowfall during winter 2008/2009 with surface snow cover always $<8 \mathrm{~cm}$. No $\mathrm{PM}_{2.5}>35 \mu \mathrm{g} \mathrm{m}^{-3}$ were recorded for winter 2008/2009 despite some $\Delta T$ that were as high as the winter 2009/2010 exceedance days. On the other hand, days with deep snow cover but no inversion saw only moderate $\mathrm{PM}_{2.5}$ levels.

The combination of high 24-h $\Delta T$ and snow cover increases the chance of prolonged primary aerosol accumaltion and secondary aerosol (e.g., ammonium nitrate $\left[\mathrm{NH}_{4} \mathrm{NO}_{3}\right]$ and secondary organic carbon [SOC]) formation, thus leading to $\mathrm{PM}_{2.5}$ episodes. In addition, snow cover necessitates application of de-icing material during snow plowing and blowing. These activities increase the use of diesel and gasoline engines that may emit more primary $\mathrm{PM}_{2.5}$ and $\mathrm{NO}_{\mathrm{x}}$ (a nitrate $\left[\mathrm{NO}_{3}^{-}\right]$precursor) than during drier periods. More cold starts for commuters can also increase emissions over those found during warmer weather (Cadle et al., 2001; Chen et al., 2001; Weilenmann et al., 2009; Nam et al., 2010).

\subsection{Chemical characteristics of $\mathbf{P M}_{2.5}$ episodes}

$\mathrm{PM}_{2.5}$ mass (speciation mass hereafter unless mentioned otherwise) and speciation data acquired from AQS contain uncertainty estimates for all variables except organic carbon (OC), elemental carbon (EC), and thermal carbon fractions by the IMPROVE_A protocol (Chow et al., 2007a, 2011). In addition to $\mathrm{OC}$ and EC, there are 48 elemental concentrations reported along with water soluble ammonium $\left(\mathrm{NH}_{4}^{+}\right)$, $\mathrm{NO}_{3}^{-}$, sulfate $\left(\mathrm{SO}_{4}^{=}\right)$, sodium $\left(\mathrm{Na}^{+}\right)$, and potassium $\left(\mathrm{K}^{+}\right)$.
Mass closure for the $\mathrm{PM}_{2.5}$ samples was calculated by summing $\mathrm{NH}_{4}^{+}, \mathrm{NO}_{3}^{-}, \mathrm{SO}_{4}^{=}$, organic matter $(\mathrm{OM}), \mathrm{EC}$, crustal material, and salt (potentially from de-icing materials) as the reconstructed mass (Malm et al., 1994; Chen et al., 2002), where:

$\mathrm{OM}=1.4 \times[\mathrm{OC}]$

Crustal Material $=2.2 \times[\mathrm{Al}]+2.49 \times[\mathrm{Si}]+1.64 \times[\mathrm{Ca}]$

$$
+2.42 \times[\mathrm{Fe}]+1.94 \times[\mathrm{Ti}]
$$

Salt $=\left[\mathrm{Na}^{+}\right]+[\mathrm{Cl}]$

Figure 4 shows the time series of measured and reconstructed $\mathrm{PM}_{2.5}$ mass during the winter 2008/2009 and 2009/2010, while Fig. 5 compares concentrations of major constitutes between the two winter periods. Since $\mathrm{SO}_{4}^{=}$ levels were low, $\mathrm{NH}_{4}^{+}$was mostly associated with $\mathrm{NO}_{3}^{-}$ as $\mathrm{NH}_{4} \mathrm{NO}_{3}$, which, along with $\mathrm{OM}$, dominated the $\mathrm{PM}_{2.5}$ mass. The sum of constituents exceeds the measured mass for samples from winter 2008/2009 except 8 December 2008 and 13 January 2009, leading to overall negative unidentified mass (UnID). For winter 2009/2010, however, UnID is generally positive. Negative UnID could result from overestimating OM. Using a multiplier of 1.4 for OC (Eq. 1) may be too high for sources such as gasoline and diesel exhausts (Russell, 2003; El-Zanan et al., 2005; Aiken et al., 2008) and the organic sampling artifact may not be sufficiently subtracted for the STN (Watson et al., 2009; Chow et al., 2010). Positive UnID indicates unaccounted species such as water. Mass closure on 30 December 2009 and 20 January 2010 was particularly poor, raising questions with regard to mass measurements for the two days.

The higher average $\mathrm{PM}_{2.5}$ concentration during winter 2009/2010 mainly resulted from larger $\mathrm{NH}_{4} \mathrm{NO}_{3}$ and UnID contributions (Fig. 5). Despite high OM concentrations on episode days (i.e., 9, 15, 18 December 2009, and 5 January 2010), OM averaged lower for winter 2009/2010 than for winter 2008/2009. As an example, the 5 January 2010 sample contains 3.2 times the $\mathrm{NO}_{3}^{-}$concentration of 1 January $2009\left(8.4 \mu \mathrm{g} \mathrm{m}^{-3}\right.$ versus $\left.2.6 \mu \mathrm{g} \mathrm{m}^{-3}\right)$ and a higher UnID $\left(4.6 \mu \mathrm{g} \mathrm{m}^{-3}\right)$ but with only comparable OM $\left(17.2 \mu \mathrm{g} \mathrm{m}^{-3}\right.$ versus $18.5 \mu \mathrm{g} \mathrm{m}^{-3}$ for 5 January 2010 and 1 January 2009, respectively). The Teflon-membrane filters were weighed at $30-40 \% \mathrm{RH}$, and water strongly bound to $\mathrm{NH}_{4} \mathrm{NO}_{3}$ might not be removed completely due to a hysteresis effect (Speer et al., 2003). If so, elevated $\mathrm{NH}_{4} \mathrm{NO}_{3}$ was the main cause of $\mathrm{PM}_{2.5}$ exceedances during winter 2009/2010. This is consistent with observations from the nearby, but much larger, San Joaquin Valley, California in winter (Watson and Chow, 2002; Chow et al., 2006; Chen et al., 2007b).

Teflon-membrane filter samples and the remnants of quartz-fiber filter samples for winter 2009/2010 were retrieved from the STN archive and submitted to additional analyses (Chow and Watson, 2012), including: (1) thermal 


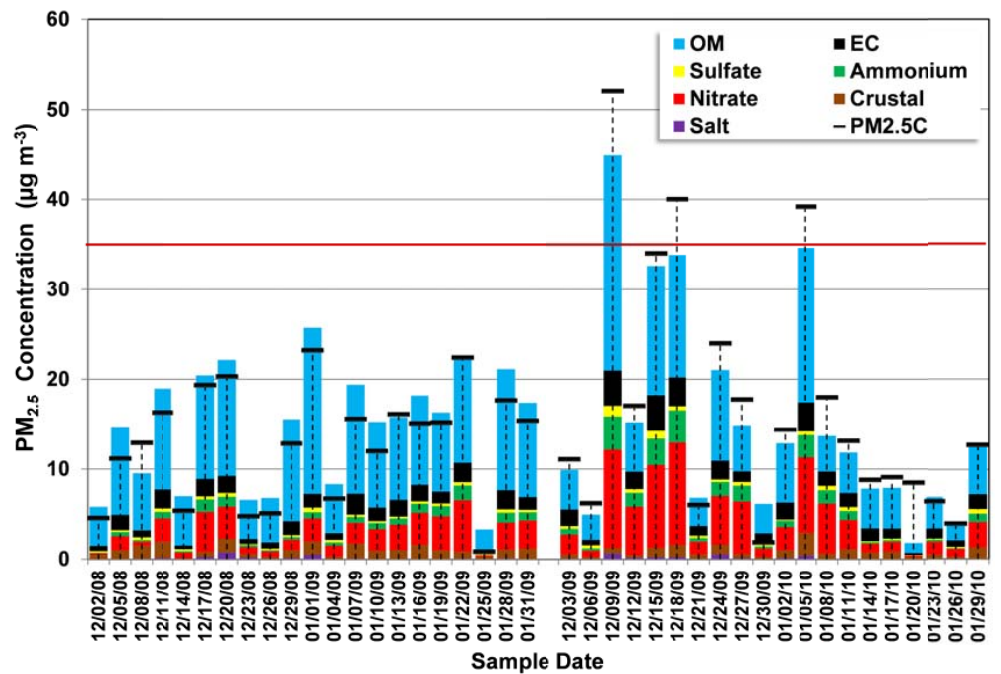

Fig. 4. $\mathrm{PM}_{2.5}$ mass reconstruction compared to speciation mass $\left(\mathrm{PM}_{2.5} \mathrm{C}\right)$ for winter $2008 / 2009$ and $2009 / 2010$. The red line indicates the USEPA 24-h PM $\mathrm{PM}_{2.5}$ National Ambient Air Quality Standard (NAAQS) of $35 \mu \mathrm{g} \mathrm{m}^{-3}$. The 15 December 2009 sample exceeds the NAAQS by FRM mass but not by speciation mass $\left(34 \mu \mathrm{g} \mathrm{m}^{-3}\right) . \mathrm{OM}=1.4 \times[\mathrm{OC}]$; Crustal Material $=2.2 \times[\mathrm{Al}]+2.49 \times[\mathrm{Si}]+1.64 \times[\mathrm{Ca}]+2.42$ $\times[\mathrm{Fe}]+1.94 \times[\mathrm{Ti}] ;$ and Salt $=\left[\mathrm{Na}^{+}\right]+[\mathrm{Cl}]$.

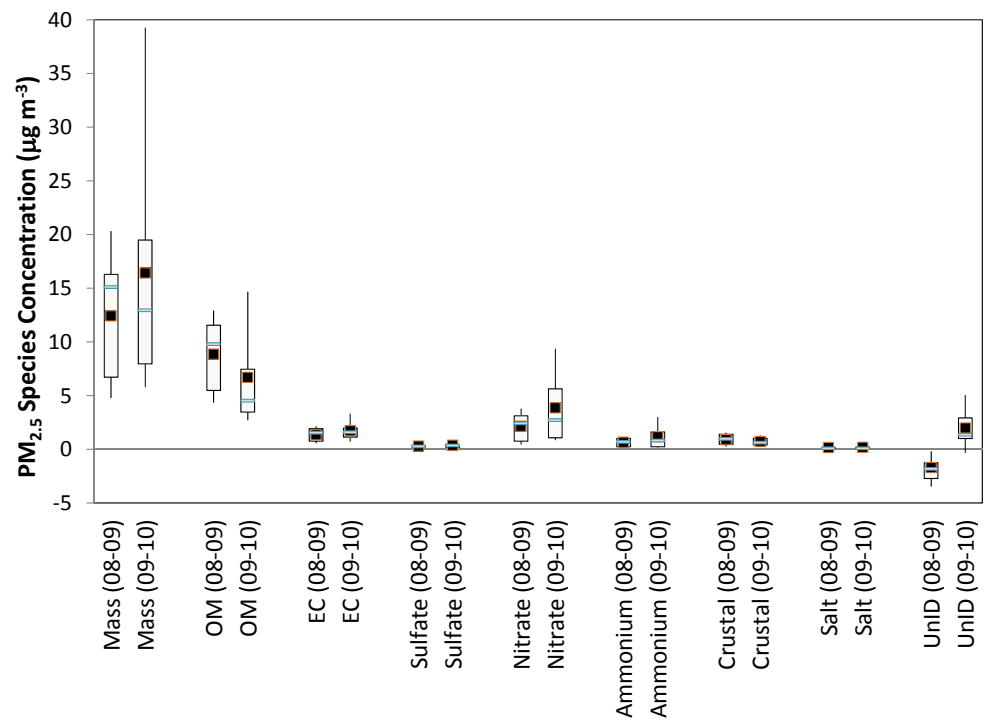

Fig. 5. Concentrations of $\mathrm{PM}_{2.5}$ mass and major constituents (i.e., square: average; bar: median; box: 25 th and 75th percentiles; whiskers: 10th and 90th percentiles) for winter 2008/2009 and 2009/2010. UnID is the unidentified mass (i.e., measured minus reconstructed PM 2.5 mass).

desorption-gas chromatography/mass spectrometry (TDGC/MS; Ho and Yu, 2004; Ho et al., 2008, 2011; Chow et al., 2007d) for non-polar organic compounds, including $\sim 120$ polycyclic aromatic hydrocarbons (PAHs), hopanes, steranes, alkanes, and alkenes; (2) water extraction/total organic carbon (TOC; Yang et al., 2003) analysis for water-soluble organic carbon (WSOC); (3) ion chromatography-pulsed amperometric detection (IC-PAD; Engling et al., 2006) for levoglucosan; and (4) two-wavelength optical transmissometer (Ahmed et al., 2009; Chen et al., 2010a) for light absorption $\left(b_{\text {abs }}\right)$ at 370 and $880 \mathrm{~nm}$. Twenty samples were analyzed for each of the species except for WSOC and levoglucosan on 18 December 2009 and 2 January 2010 where there were insufficient quartz-fiber filter remnants.

The temporal variations and relative abundances of organic species are presented in the Supplement, along with their two-month averages/signal-to-noise ratios (SNR; Fig. S1 and Table S1 of the Supplement). n-Alkanes are the most abundant organic compounds with concentrations ranging from $6.1 \mathrm{ng} \mathrm{m}^{-3}$ (20 January 2010) 


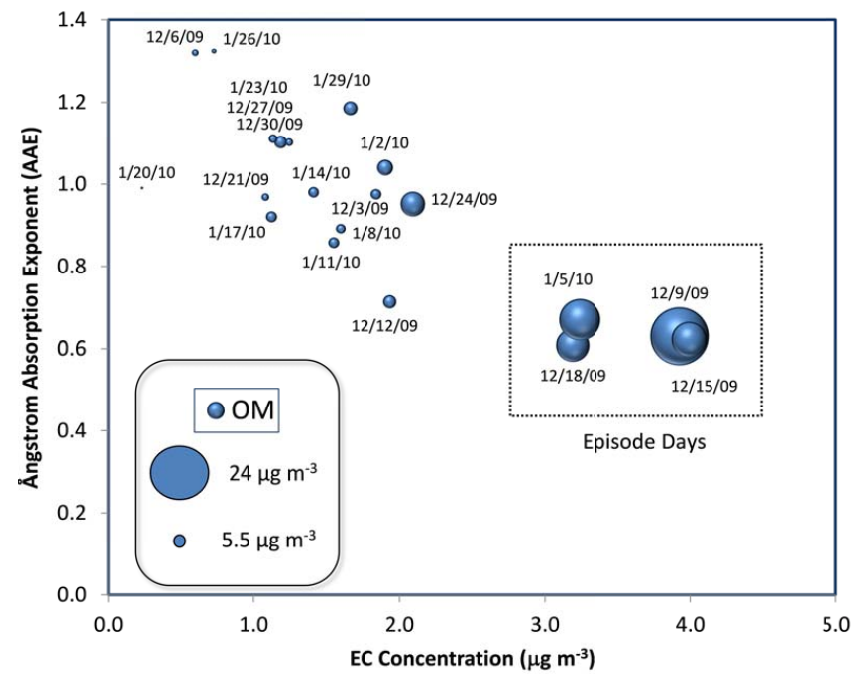

Fig. 6. Ångstrom Absorption Exponent (AAE) as a function of elemental carbon (EC) and organic material (OM) concentration. Diameter of the spheres is proportional to the OM concentration where $\mathrm{OM}=1.4 \times$ OC. Episode days exceeding the USEPA 24-h $\mathrm{PM}_{2.5}$ National Ambient Air Quality Standard (NAAQS) of $35 \mu \mathrm{g} \mathrm{m}^{-3}$ are identified.

to $79.1 \mathrm{ng} \mathrm{m}^{-3}$ (9 December 2009), containing abundant $n$-tetracosane (tetcos), $n$-hentriacontane (htricont), and $n$-pentacosane (pencos). The most abundant cyclo/branched alkanes are anteiso-dotriacontane (anteisoc32), iso-tritriactotane (isoc33), and iso-hentriacotane (isoc33). Particle-bound PAHs (p-PAHs) are air toxics that derive from many combustion sources. The sum of measured p-PAH concentrations ranges from $0.82 \mathrm{ng} \mathrm{m}^{-3}$ (2 January 2010) to $46.2 \mathrm{ng} \mathrm{m}^{-3}$ (9 December 2009). Abundant p-PAH species include cyclopenta[c,d]pyrene (cpcdpyr), retene, and benzo[b,j,k]fluoranthene (bbjkfl). Retene, a known marker for coniferous wood combustion (Ramdahl, 1983), is more enriched in the Truckee Meadows $(13 \pm 5 \%$ of total p-PAHs) than in areas dominated by mobile sources (e.g., $1 \pm 1 \%$ in El Paso, Texas; Chen et al., 2012a). Hopanes and steranes originate from oil combustion or from vehicle lube oil (Zielinska et al., 2008), and are $<5 \mathrm{ng} \mathrm{m}^{-3}$ with the dominant species being $\alpha \alpha \alpha$ 20S 24R/S-ethylcholestane (ster12), $17 \alpha[\mathrm{H}], 21 \beta[\mathrm{H}]-$ 30-norhopane (hop17), and $17 \alpha[\mathrm{H}], 21 \beta[\mathrm{H}]$-hopane (hop19).

Both WSOC and levoglucosan concentrations are high, particularly for the episode days. On 9 December 2009, WSOC reached almost $7 \mu \mathrm{g} \mathrm{m}^{-3}$ while levoglucosan exceeded $1 \mu \mathrm{g} \mathrm{m}^{-3}$. Levoglucosan has been considered as a primary marker for biomass burning (Fraser and Lakshmanan, 2000), and this supports the importance of residential wood combustion (RWC) contributions during the episode.

Aerosol $b_{\text {abs }}$ at 370 and $880 \mathrm{~nm}$ correlate well with EC concentrations $\left(r^{2}=0.9\right)$. The regression slopes are $21.3 \mathrm{~m}^{2} \mathrm{~g}^{-1}$ for $370 \mathrm{~nm}$ and $13.6 \mathrm{~m}^{2} \mathrm{~g}^{-1}$ for $880 \mathrm{~nm}$. This is consistent with EC as the dominant light-absorbing component. The Ångström absorption exponent (AAE) (Chen et al., 2006; Moosmüller et al., 2009):

$\mathrm{AAE}=\frac{\ln \left(\mathrm{b}_{\mathrm{abs}, 370}\right)-\ln \left(\mathrm{b}_{\mathrm{abs}, 880}\right)}{\ln (370)-\ln (880)}$,

ranges from 0.61 to 1.32 . Biomass burning aerosol from smoldering combustion generally shows AAE $(>1)$ higher than that from flaming combustion or motor vehicle exhausts with AAE $<1$ (Kirchstetter et al., 2004; Chakrabarty et al., 2010; Chen et al., 2010a). In this study AAE appears to be lowest during the $\mathrm{PM}_{2.5}$ episodes (Fig. 6), consistent with $b_{\text {abs }}$ contributions mostly from flaming RWC and/or engine exhausts. The spectral characteristics of $b_{\mathrm{abs}}$ for the episode and non-episode periods are confirmed by in situ, continuous measurements at a nearby site (Gyawali et al., 2012). Smoldering contributions seem to be less important during the winter episodes.

\section{Chemical mass balance source apportionment}

The Effective Variance solution (Watson et al., 1984) to the CMB equations (EV-CMB) uses both source profiles and ambient concentrations as inputs to calculate source contribution estimates (SCEs) and associated uncertainties (Watson et al., 1984, 2008; Chow and Watson, 2002; Held et al., 2005; Chen et al., 2010b). EV-CMB was applied to each RENO_C speciated sample.

\subsection{Source profiles}

Source profiles relevant to sources in the Truckee Meadows are identified and referenced in supplemental Table S2. Major source types include: (1) geological materials; (2) motor vehicles (gasoline and diesel); (3) biomass burning (RWC and open burning); (4) cooking; (5) utility combustion; and (6) secondary aerosol, corresponding to the local $\mathrm{PM}_{2.5}$ emission inventory (Ling-Barnes, 2010). Two fugitive dust samples (i.e., paved road dust - RNOPVRD, surface soils from a vacant lot - RNOSOIL) were obtained from representative locations around the RENO_C site along with two types of de-icing material (RNOSalt1 and RNOSalt2). These samples were dried, sieved, resuspended, and sampled onto filters (Chow et al., 1994) for chemical analyses identical to those for ambient samples, except that WSOC and levoglucosan were not quantified and set to zero owing to low OC contents (1.1-14.9\%, see Table S3).

Engine exhaust profiles considered include those acquired from the National Renewable Energy Laboratory Gas/Diesel Split Study (Fujita et al., 2007a, b) and the Las Vegas Carbon Source Apportionment Study (LVCSAS, Green et al., 2012b). These profiles are more recent and contain full organic speciation except for alkanes. They have been used in other EV-CMB applications (Chow et al., 2007c; Green et 
al., 2012a). The Gas/Diesel Split profiles were based on dynamometer tests of 57 gasoline and 32 diesel vehicles while LVSAS adopted an in-plume monitoring system (Nussbaum et al., 2009; Zhu et al., 2009) at traffic intersections where air was dominated by a mixture of motor vehicle exhausts. Both studies were conducted in Nevada or neighboring California with vehicles and fuels similar to those of the Truckee Meadows.

The RWC source profiles resulted from tests during the Central California $\mathrm{PM}_{10} / \mathrm{PM}_{2.5}$ Air Quality Study (CRPAQS; Fitz et al., 2003) and the Lake Tahoe Source Characterization Study (LTSCS; Kuhns et al., 2004). CRPAQS focused on fireplace emissions while LTSCS tested both fireplaces and woodstoves. Both studies examined hardwood (i.e., oak, almond, and eucalyptus) and softwood (i.e., pine, tamarack, and juniper) combustion separately, resulting in six composite profiles. Levoglucosan's abundance ranges from 0.1 to $55.5 \%$ among these six profiles. RWC emission compositions are highly variable depending on fuel and combustion conditions, as indicated by Chen et al. (2007a, 2010a). Open burning, including wildland fires, is not expected to contribute during winter months.

Due to the proximity of the RENO_C site to a Mexican restaurant, a meat cooking profile (BVCOOK, a composite of charbroiled chicken, chicken over propane, and charbroiled hamburger) as part of CRPAQS was included. Chow et al. (2007c) found meat cooking to be an important contributor at the Fresno supersite during winter. The markers for meat cooking are often associated with polar compounds such as cholesterol, palmitic acid, palmitoleic acid, stearic acid, and oleic acid (Fraser et al., 2003; Rinehart et al., 2006). However, the archived ambient samples were not amenable to analyses for these components.

Most of the reported point source profiles do not contain organic markers, but no large stationary emitters are located within the Truckee Meadows. Long-range transport from distant point sources is also low during winter. Point source profiles are therefore not included in the EV-CMB modeling. Secondary $\mathrm{NO}_{3}^{-}$and $\mathrm{SO}_{4}^{=}$sources are represented by pure $\mathrm{NH}_{4} \mathrm{NO}_{3}$ (AMNIT) and $\left(\mathrm{NH}_{4}\right)_{2} \mathrm{SO}_{4}$ (AMSUL) profiles, respectively. Secondary OC is represented by a profile (SOC) containing exclusively (100\%) OC (Watson, 1979). This is equivalent to using the $\mathrm{OC} / \mathrm{EC}$ ratio method to estimate SOC.

Table S1 indicates the EV-CMB fitting species. Important source markers that are commonly detectable in ambient samples and their corresponding sources include (e.g., Chow et al., 2007c; Watson et al., 2008): (1) Al, Si, Ca, Fe, Mn, $\mathrm{K}, \mathrm{Ti}$, and $\mathrm{Sr}$ for geological material/minerals; (2) EC and hopanes for diesel exhaust; (3) indeno[1,2,3,cd]pyrene (incdpy), benzo[g,h,i]perylene (bghipe), and coronene (corone) for gasoline engine exhaust; (4) $\mathrm{K}^{+}$, retene, and levoglucosan for biomass burning; (5) pristane, and phytane for cooking; (6) $\mathrm{Cu}, \mathrm{Zn}, \mathrm{As}, \mathrm{Se}, \mathrm{Br}, \mathrm{Pb}$ for industrial point sources; (7) $\mathrm{Na}^{+}, \mathrm{Cl}$ for de-icing material; and (8) $\mathrm{S}$, and $\mathrm{NO}_{3}^{-}$for secondary inorganics. OC is not a specific marker but it is a major $\mathrm{PM}_{2.5}$ constituent. Temperature-resolved carbon fractions were not used as they were mostly determined by the IMPROVE (Chow et al., 1993) protocol in source profiles but by the IMPROVE_A (Chow et al., 2007a) protocol in ambient samples acquired after 2007. The two protocols are known to yield comparable OC and EC measurements but possibly differ for carbon fractions (Chow et al., 2005, 2007a; Chen et al., 2012b).

\subsection{Sensitivity tests}

EV-CMB sensitivity tests were applied to data from several samples to evaluate the performance of different source profile combinations in terms of correlation $\left(r^{2}\right)$, root mean square difference $\left(\chi^{2}\right)$, and percent of mass explained (\%MASS) (Watson and Chow, 2012). The initial source profile combination was modified in subsequent trials to examine changes in the SCEs and EV-CMB performance measures. Often, only one profile in each source type may be included since similar profiles result in collinearity, nonconvergence, and/or negative source contributions. An acceptable solution requires \%MASS between 0.9 and 1.1, $r^{2}>0.9$, and $\chi^{2}<2$. The modified pseudo-inverse normalized (MPIN) matrix (Kim and Henry, 1999) would indicate the most influential species (e.g., MPIN value $>0.5$ ) for each source type.

Table S4 illustrates two sensitivity test examples (an episode day on 5 January 2010 and a median loading day on 17 January 2010). Better EV-CMB fits to the data result from a combination of paved road dust (RNOPVRD), road salt (RNOSALT2), mobile source (gasoline and diesel engine exhaust; GAS and DIESEL, respectively), RWC (fireplace and woodstove burning hardwoods; CRBURN_H and LTWS_H), and secondary (AMNIT and AMSUL) source profiles. The DIESEL profile may represent both on-road and off-road diesel engine emissions. Gasoline-engine exhaust contributions appear to be minor compared with those from diesel engines. Including softwood RWC profiles in the CMB model always lowers the overall model performance.

Including the cooking (BVCOOK) profile improves performance measures (e.g., lower $\chi^{2}$ and higher \%MASS). However, the cooking contribution would be comparable to or even greater than the combined contribution from gasoline and diesel engine exhaust (Table S4). The MPIN matrix indicates that OC is the only species influencing the cooking source. Due to the lack of more specific cooking markers such as cholesterol and palmitoleic acid, BVCOOK was deselected. Adding SOC into the mix led to non-convergence for both samples.

The MPIN matrices for the selected source combination (Table S5) indicates that the most important diesel engine exhaust marker is EC, followed by $\mathrm{Zn}$ while the gasoline engine exhaust contribution is marked by coronene. indeno[ $[1,2,3, \mathrm{~cd}]$ pyrene and benzo[g,h,i]perylene are more 
associated with the wood stove profile (i.e., LTWS_H), along with levoglucosan, $\mathrm{OC}$, and $17 \alpha(\mathrm{H}), 21 \beta(\mathrm{H})$-hopane. This explains the low gasoline engine exhaust SCEs by EVCMB. The fireplace emission (i.e., CRBURN_H) is marked by retene and $\mathrm{K}^{+} . \mathrm{Si}$ is the most influential species for paved road dust profile (i.e., RNOPVRD), followed by $\mathrm{Al}$ and $\mathrm{Ca}$. $\mathrm{Fe}$, however, is associated with a de-icing profile (i.e., RNOSalt2) along with $\mathrm{Na}^{+}$and $\mathrm{Cl}$. Water-soluble iron cyanide compounds are widely used as anticaking agents in road salt. $\mathrm{NO}_{3}^{-}$and $\mathrm{S}$ are unambiguous markers for secondary $\mathrm{NH}_{4} \mathrm{NO}_{3}$ and $\left(\mathrm{NH}_{4}\right)_{2} \mathrm{SO}_{4}$, respectively.

Figure 7 compares measured and calculated $\mathrm{PM}_{2.5}$ species concentrations. For the 5 January 2010 sample, the EV-CMB solution explains measured species well except for the carbon fractions (EC1, EC2, and OP, not included in the fitting but calculated from SCEs), Pb, As, 22R-17 $\alpha(\mathrm{H}), 21 \beta(\mathrm{H})-$ 30,31,32-Trishomohopane (hop27), and phytane. In addition, $\mathrm{Cl}, \mathrm{Ti}, \mathrm{Br}, \mathrm{Cu}, \mathrm{Rb}$, and all hopanes were not fitted as well for the 17 January $2010 \mathrm{PM}_{2.5}$ sample. None of these species, however, are unique source markers. Removing these species somewhat alters the SCEs but the changes are within the uncertainty intervals.

\subsection{Source contribution estimates}

Figure 8 shows the winter 2009/2010 SCEs for $\mathrm{PM}_{2.5}$, OC, and EC. RWC is resolved for all samples, though the partition between fireplace and woodstove contributions varies. Woodstove contributions are missing for the 18 December 2009 and 2 January 2010 samples because levoglucosan data were not available on these two days. Diesel contributions show up every day except for 26 January 2010 when only gasoline engine exhaust was detected. This abnormality is hard to explain physically, and it is a reminder of the uncertainty inherent in separating diesel and gasoline source contributions even with organic markers. De-icing contributions are also resolved for every sample except 26 January 2010, while paved road dust does not appear on 3-9, 15-18, and 30 December 2009. De-icing material contributed more to $\mathrm{PM}_{2.5}$ than paved road dust during December 2009, while the opposite was true during January 2010. This is consistent with more snowfalls in December 2009 since snow covers reduce fugitive dust but increase salting and de-icing activities. Secondary $\left(\mathrm{NH}_{4}\right)_{2} \mathrm{SO}_{4}$ is resolved for all samples except for 2 January 2010, although its contribution never exceeds $0.25 \mu \mathrm{g} \mathrm{m}^{-3}$. EV-CMB-calculated $\mathrm{PM}_{2.5}$ mass concentrations are generally lower than measured $\mathrm{PM}_{2.5}$. For the two days with poor mass closure (30 December 2009 and 20 January 2010), model calculated $\mathrm{PM}_{2.5}$ mass are closer to the reconstructed mass than the gravimetric mass. A strong correlation $\left(r^{2}=0.89\right)$ between the unexplained $\mathrm{PM}_{2.5}$ mass and secondary $\mathrm{NH}_{4} \mathrm{NO}_{3}$ (AMNIT) contribution supports water associated with $\mathrm{NH}_{4} \mathrm{NO}_{3}$ as a major component of unexplained mass (Fig. 9).
RWC, diesel engine exhaust, and secondary $\mathrm{NH}_{4} \mathrm{NO}_{3}$ were the major $\mathrm{PM}_{2.5}$ contributors during NAAQS exceedances. The highest RWC contribution of $26.6 \mu \mathrm{g} \mathrm{m}^{-3}$ or $51 \%$ of $\mathrm{PM}_{2.5}$ mass occurred on 9 December 2009. Most of the RWC was attributed to fireplace emissions. An intense and persistent inversion layer and deep snow cover, coupled with low temperatures during the day (daily mean: $-13^{\circ} \mathrm{C}$ ), enhanced RWC emissions and accumulation. Secondary $\mathrm{NH}_{4} \mathrm{NO}_{3}$ accounted for $26.7 \%$ of $\mathrm{PM}_{2.5}$ mass on 9 December 2009. Particulate $\mathrm{NH}_{4} \mathrm{NO}_{3}$ is also favored by low temperatures and high RH (Watson et al., 1994; West et al., 1999; Chow et al., 2008). Diesel engine exhaust explained another $6.5 \%$ of $\mathrm{PM}_{2.5}$ while other sources were minor contributors $(0-3 \%)$. For the other episode days $(15,18$ December 2009, and 5 January 2010), RWC contributions were lower (11-39\%) while diesel contributions were higher (13-22\%). Higher ambient temperatures, i.e., daily mean: 0-1 ${ }^{\circ} \mathrm{C}$, compared to those of 9 December 2009 may explain the difference. Nevertheless, ambient temperatures on the three days appear to be low enough for $\mathrm{NH}_{4} \mathrm{NO}_{3}$ formation $-\mathrm{NH}_{4} \mathrm{NO}_{3}$ fractions ranged from 27 to $37 \%$. Paved road dust was an important contributor $(5.7 \%)$ only on 5 January 2010.

RWC from fireplaces also dominated the ambient OC concentrations (Fig. 8). On 15 and 18 December 2009, diesel exhaust was almost as important as RWC as an OC source. The unexplained OC, up to $44 \%$ of measured OC, may be in part attributed to a positive organic sampling artifact, which has not been adequately corrected on the STN samples (Chow et al., 2010). Since OC was quantified on quartz-fiber filters and mass was measured on Teflon-membrane filters, this artifact should not contribute to the unexplained $\mathrm{PM}_{2.5}$ mass. Certainly the missing OC might also result from SOC and/or differences between the selected source profiles and the actual (but unknown) profiles typical of local RWC emissions. The EV-CMB model explains EC better than OC. There is no organic sampling artifact associated with EC. Diesel engine exhaust is the dominant EC source.

\subsection{Origins of secondary ammonium nitrate}

Comparing $\mathrm{PM}_{2.5}$ chemical speciation of winter 2009/2010 with winter 2008/2009 shows that the higher secondary $\mathrm{NH}_{4} \mathrm{NO}_{3}$ lifted $\mathrm{PM}_{2.5}$ concentrations over the $35 \mu \mathrm{g} \mathrm{m}{ }^{-3}$ threshold. The formation of $\mathrm{NH}_{4} \mathrm{NO}_{3}$ may depend on gaseous ammonia $\left(\mathrm{NH}_{3}\right)$ or nitric acid $\left(\mathrm{HNO}_{3}\right.$; derived from $\mathrm{NO}_{\mathrm{x}}$ emissions) concentrations and be influenced by ambient temperature and RH (Watson and Chow, 2002). An ion balance shows a full neutralization of $\mathrm{NO}_{3}^{-}$, and $\mathrm{SO}_{4}^{2-}$ by $\mathrm{NH}_{4}^{+}$ during the $\mathrm{PM}_{2.5}$ episodes and so $\mathrm{NO}_{\mathrm{x}}$ emissions and oxidation likely limit $\mathrm{NH}_{4} \mathrm{NO}_{3}$ formation in the valley. A good correlation of 24-h $\mathrm{NO}_{\mathrm{x}}$ and AMNIT $\left(r^{2}=0.82\right)$ is found for winter 2009/2010.

Most wintertime $\mathrm{NO}_{\mathrm{x}}$ is generated from local sources, particularly mobile and RWC emissions, and so is $\mathrm{NO}_{3}^{-}$. 


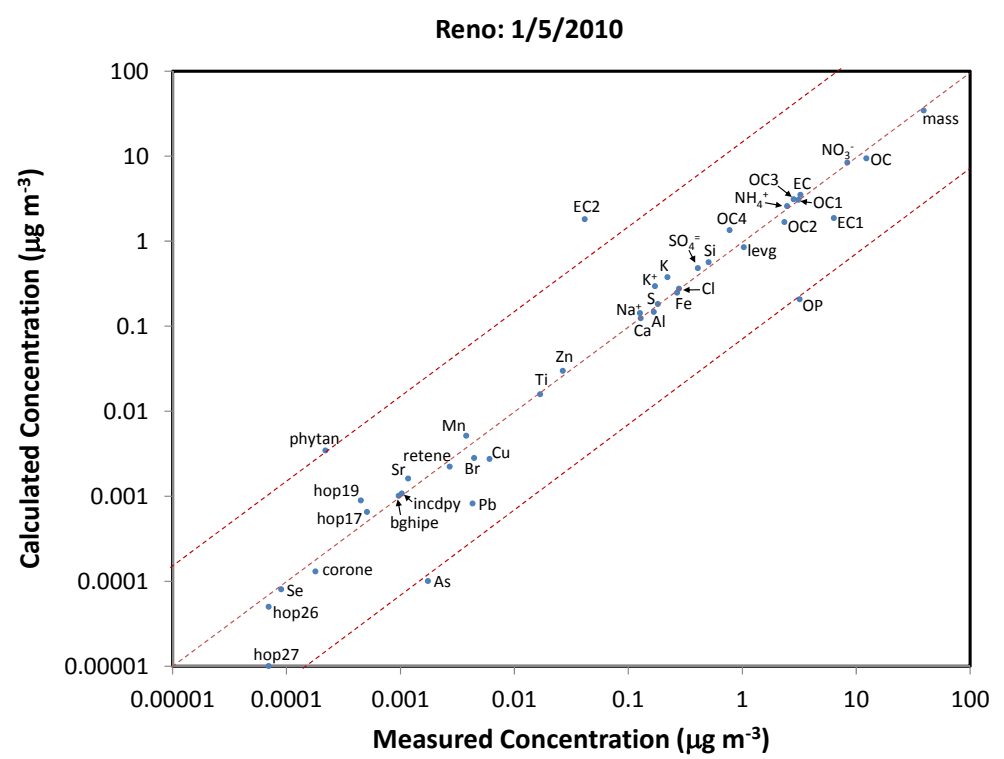

(a)

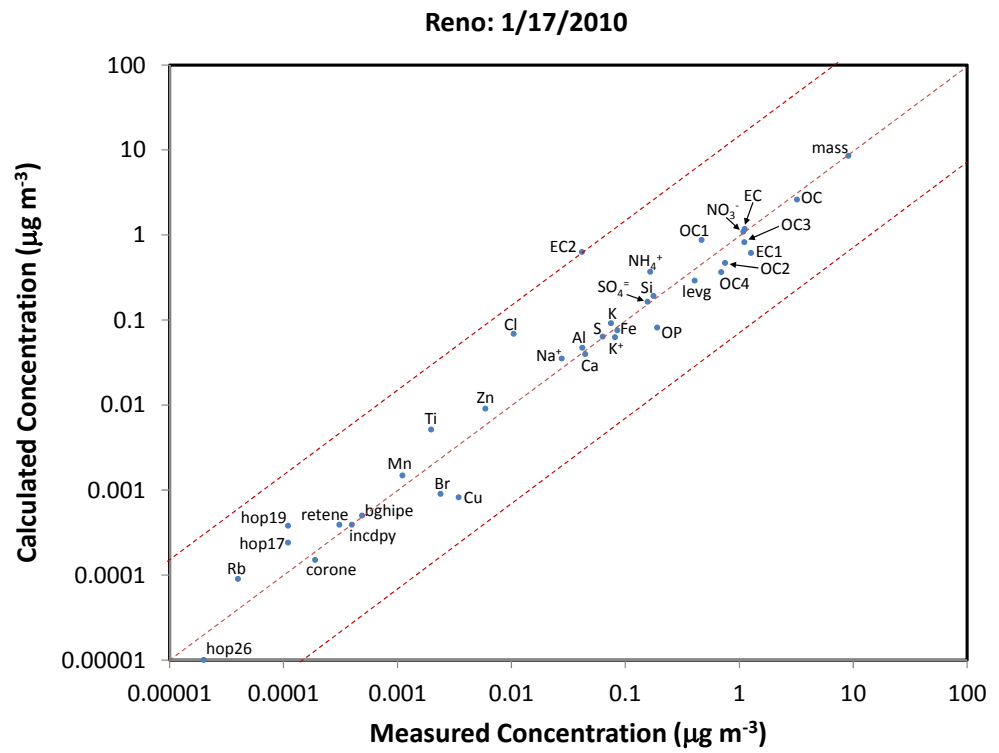

(b)

Fig. 7. Comparisons of EV-CMB calculated versus measured $\mathrm{PM}_{2.5}$ species for: (a) 5 January 2010 and (b) 17 January 2010 samples from the Reno monitoring site (RENO_C). See Supplement Table S0 for definitions of organic species abbreviations.

Compression-ignition engines used in diesel vehicles have long been considered important $\mathrm{NO}_{\mathrm{x}}$ sources owing to a high combustion temperature (Lloyd and Cackette, 2001; Chow, 2001). Biomass burning, especially high-temperature flaming combustion, may also generate substantial $\mathrm{NO}_{\mathrm{x}}$ (Chen et al., 2007a, 2010a). Other Truckee Meadows $\mathrm{NO}_{\mathrm{x}}$ sources include natural gas combustion in furnaces and boilers (LingBarnes, 2010), which have higher emissions during winter than other seasons. Coal-fired power plant contributions and other distant sources can be excluded as $\mathrm{NO}_{\mathrm{x}}$ and $\mathrm{NO}_{3}^{-}$con- tributors during winter owing to their great distance from the Truckee Meadows.

To a first approximation, secondary $\mathrm{NH}_{4} \mathrm{NO}_{3}$ affiliated with mobile sources or RWC was estimated from regressing AMNIT contributions against mobile and RWC contributions. A robust regression method (Huber, 1981) was applied which involves iterative reweighting of the input data values to lessen the influence of extreme values. The two RWC sources (i.e., CRBURN_H and LTWS_H) were combined to form an overall RWC contribution while the diesel and gasoline sources (i.e., DIESEL and GAS) were pooled to 

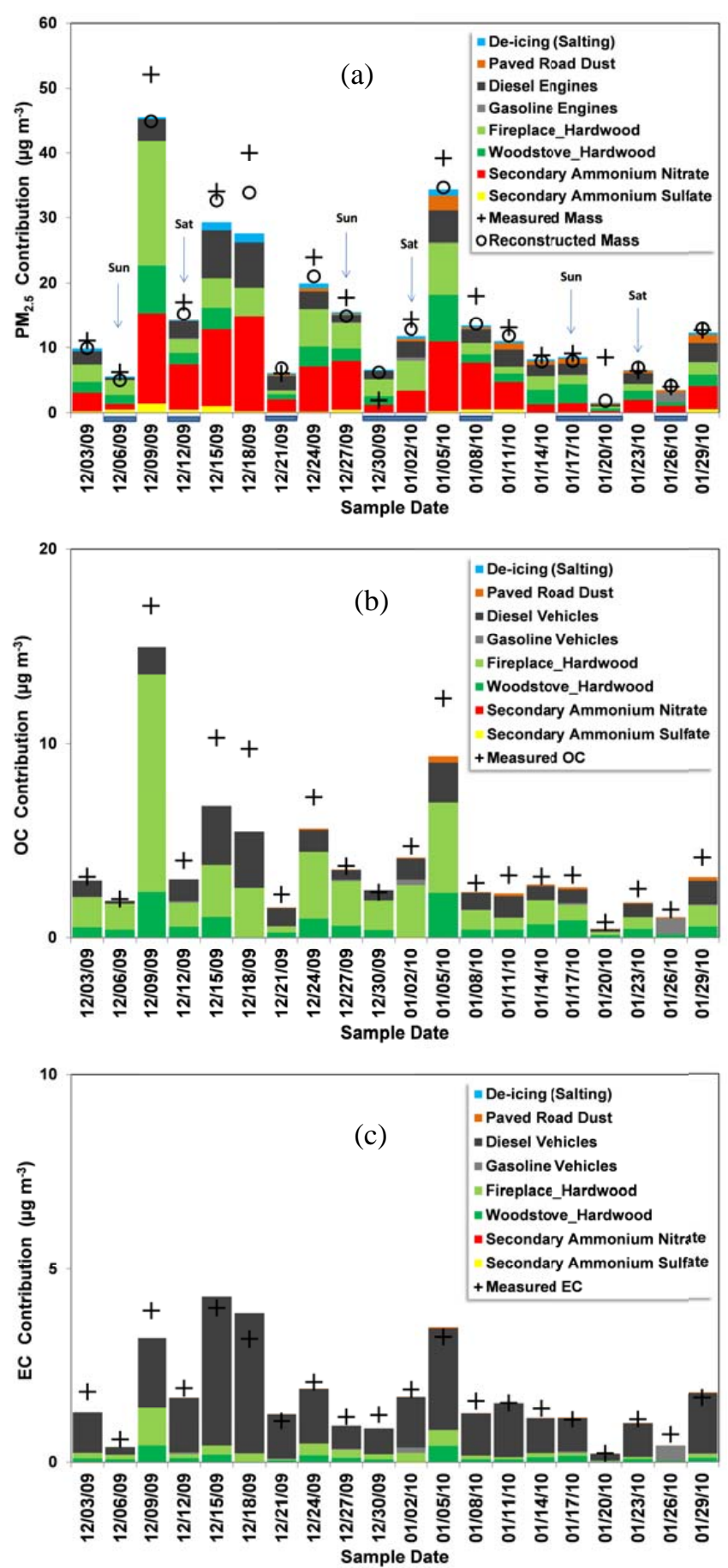

Fig. 8. EV-CMB $\mathrm{PM}_{2.5}$ source apportionment for: (a) mass, (b) OC, and (c) EC. Stacked columns indicate model estimates, which are compared with measured and reconstructedmass concentrations. Weekends are noted in (a). Snowy days are marked by a blue bar under the column in (a). Snow cover typically accumulates during or after the snowfall.

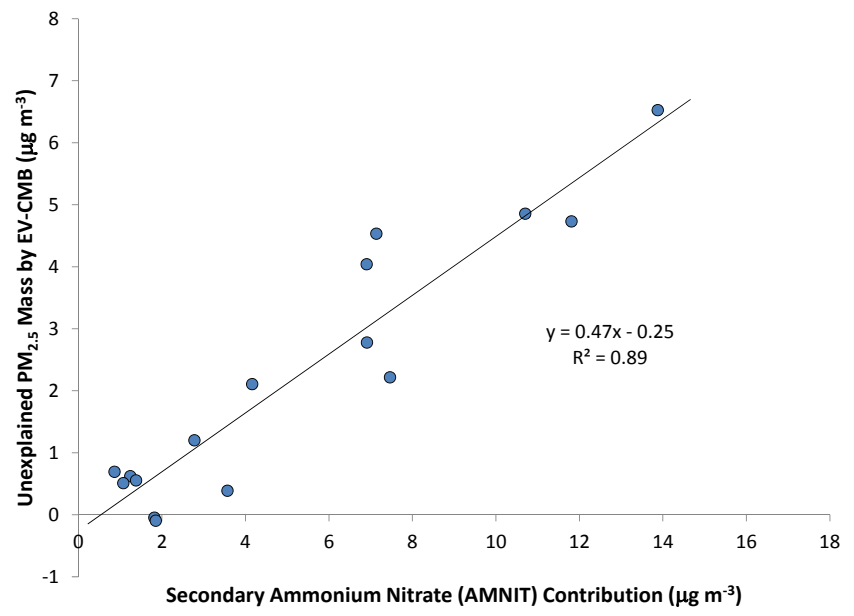

Fig. 9. Relationship between unexplained $\mathrm{PM}_{2.5}$ mass and secondary ammonium nitrate contribution by EV-CMB analysis. Four data points were excluded due to either missing levoglucosan measurements (18 December 2009 and 2 January 2009) or very poor mass closure (30 December 2009 and 20 January 2010).

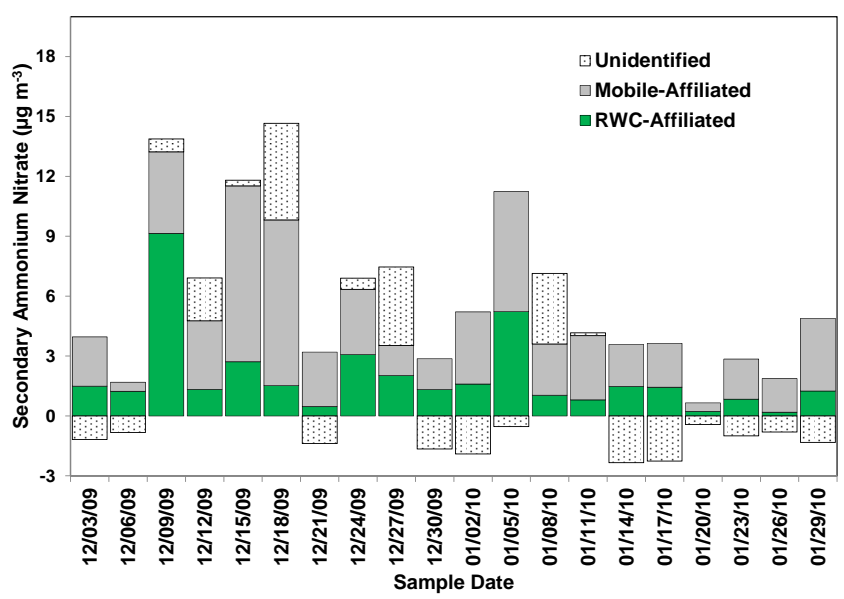

Fig. 10. Source apportionment of secondary ammonium nitrate by robust multiple linear regression.

represent the mobile contribution. The regression of AMNIT against the RWC and mobile contributions together yields a good correlation $\left(r^{2}=0.81\right)$, better than the regression correlations against RWC or mobile contributions alone $\left(r^{2}=\right.$ $0.45-0.65$ ). The regression coefficients are 0.34 and 1.20 for RWC and mobile sources, respectively, suggesting that 0.34 and $1.2 \mu \mathrm{g} \mathrm{m}{ }^{-3}$ secondary $\mathrm{NH}_{4} \mathrm{NO}_{3}$ is produced per $\mu \mathrm{g} \mathrm{m}^{-3}$ of primary $\mathrm{PM}_{2.5}$ emitted from the RWC and mobile sources, respectively.

Figure 10 shows mobile- and RWC-affiliated secondary $\mathrm{NH}_{4} \mathrm{NO}_{3}$, which explain total $\mathrm{NH}_{4} \mathrm{NO}_{3}$ (i.e., AMNIT) levels for three of four high $\mathrm{PM}_{2.5}$ days: 9, 15 December 2009, and 5 January 2010. (Note: the RWC contribution on 18 December 2009 is underestimated due to missing levoglucosan 
measurement.) Although the mobile sources did not contribute to primary $\mathrm{PM}_{2.5}$ as much as RWC during winter 2009/2010, the mobile-source contribution might be responsible for $\sim 2 / 3$ of secondary $\mathrm{NH}_{4} \mathrm{NO}_{3}$.

\section{Conclusions}

The Truckee Meadows is an urban valley in the arid west of the US with light-to-moderate snowfall and frequent subsidence in winter. The formation of $\mathrm{PM}_{2.5}$ episodes shows meteorological and chemical characteristics that are likely common for many urban valleys in the Western Cordillera.

First, the highest $\mathrm{PM}_{2.5}$ concentrations are accompanied by intense and prolonged (multi-day) temperature inversions, snow on the ground, and low wind speeds. These variables are inter-related, as snow cover increases the reflectance of sunlight, thereby decreasing heating at the surface that would break up the inversion. Most of the surface heating that remains is absorbed as latent heat, melting the snow rather than raising the surface temperature. The prolonged inversion creates a stagnant condition that inhibits ventilation by wind.

Second, $\mathrm{OC}$ and $\mathrm{EC}$ dominate the $\mathrm{PM}_{2.5}$ mass, but during episodes much elevated $\mathrm{NH}_{4} \mathrm{NO}_{3}$ and unidentified mass concentrations drive $\mathrm{PM}_{2.5}$ levels over the $35 \mu \mathrm{g} \mathrm{m}^{-3}$ threshold. The low temperatures and higher RH associated with snow cover and melting snow encourage a shift in equilibrium for gaseous $\mathrm{HNO}_{3}$ and $\mathrm{NH}_{3}$ to form particulate $\mathrm{NH}_{4} \mathrm{NO}_{3}$, thereby increasing its contribution to $\mathrm{PM}_{2.5}$ mass. Liquid water associated with $\mathrm{NH}_{4} \mathrm{NO}_{3}$ explains most unidentified mass in the samples. The water may not completely leave these particles until RH decreases below $30 \%$.

An EV-CMB receptor model suggests that RWC, diesel exhaust, and $\mathrm{NH}_{4} \mathrm{NO}_{3}$ were major contributors to $\mathrm{PM}_{2.5}$ in the Truckee Meadows during winter 2009/2010. RWC contributions ranged from $11-51 \%$ of $\mathrm{PM}_{2.5}$ mass on four $35 \mu \mathrm{g} \mathrm{m}^{-3}$ exceedance days $(9,15,18$ December 2009, and 5 January 2010). Most of the RWC was attributed to fireplaces burning hardwoods. The wide range of RWC contribution may reflect different ambient temperatures, as lower temperatures increase home heating demand. Secondary $\mathrm{NH}_{4} \mathrm{NO}_{3}$ accounted for 27-37\% of $\mathrm{PM}_{2.5}$ while diesel engine exhaust explained 7-22\% of $\mathrm{PM}_{2.5}$. Paved road dust and de-icing materials were minor, but detectable, contributors. Gasoline engine exhaust was a small contributor, as was secondary $\left(\mathrm{NH}_{4}\right)_{2} \mathrm{SO}_{4}$ that never exceeded a $0.25 \mu \mathrm{g} \mathrm{m}^{-3}$ contribution to $\mathrm{PM}_{2.5}$ mass. Contributions from large industrial sources (e.g., coal-fired power plants) were not quantified, though all the known large point sources are distant from the Truckee Meadows and transport is low during winter stagnations. Neither cooking nor SOC contributions were resolved.

A multiple linear regression of the secondary $\mathrm{NH}_{4} \mathrm{NO}_{3}$ contribution on the mobile source and wood burning contributions suggests that about $2 / 3$ of the $\mathrm{NH}_{4} \mathrm{NO}_{3}$ is associated with mobile source emissions and 1/3 with RWC emissions, consistent with most of the $\mathrm{NO}_{3}^{-}$deriving from engine $\mathrm{NO}_{\mathrm{x}}$ emissions. Reducing use of diesel-powered equipment and restricting domestic burning for unfavorable pollution meteorology forecasts should contribute to the prevention of future NAAQS exceedances.

\section{Supplementary material related to this article is available online at: http://www.atmos-chem-phys.net/12/ 10051/2012/acp-12-10051-2012-supplement.pdf.}

Acknowledgements. This study was supported in part by the Washoe County Air Quality Management Division (WCAQMD). In particular, the authors thank Steve Kohl, Dana Trimble, Jerome Robles, and Steven Gronstal of the Desert Research Institute Environmental Analysis Facility for assistance in geological sample collection and resuspension for chemical speciation and Jo Gerrard for assembling and editing the manuscript. The conclusions are those of the authors and do not necessarily reflect the views of the sponsoring agencies.

Edited by: T. Kirchstetter

\section{References}

Ahmed, T., Dutkiewicz, V. A., Shareef, A., Tuncel, G., Tuncel, S., and Husain, L.: Measurement of black carbon (BC) by an optical method and a thermal-optical method: Intercomparison for four sites, Atmos. Environ., 43, 6305-6311, 2009.

Aiken, A. C., DeCarlo, P. F., Kroll, J. H., Worsnop, D. R., Huffman, J. A., Docherty, K. S., Ulbrich, I. M., Mohr, C., Kimmel, J. R., Sueper, D., Sun, Y., Zhang, Q., Trimborn, A., Northway, M., Ziemann, P. J., Canagaratna, M. R., Onasch, T. B., Alfarra, M. R., Prevot, A. S. H., Dommen, J., Duplissy, J., Metzger, A., Baltensperger, U., and Jimenez, J. L.: O/C and OM/OC ratios of primary, secondary, and ambient organic aerosols with high-resolution time-of-flight aerosol mass spectrometry, Environ. Sci. Technol., 42, 4478-4485, 2008.

Bachmann, J. D.: Will the circle be unbroken: A history of the US national ambient air quality standards-2007 Critical Review, J. Air Waste Manage., 57, 652-697, 2007.

Cadle, S. H., Mulawa, P., Groblicki, P., Laroo, C., Ragazzi, R. A., Nelson, K., Gallagher, G., and Zielinska, B.: In-use light-duty gasoline vehicle particulate matter emissions on three driving cycles, Environ. Sci. Technol., 35, 26-32, 2001.

Chakrabarty, R. K., Moosmüller, H., Chen, L.-W. A., Lewis, K. Arnott, W. P., Mazzoleni, C., Dubey, M. K., Wold, C. E., Hao, W. M., and Kreidenweis, S. M.: Brown carbon in tar balls from smoldering biomass combustion, Atmos. Chem. Phys., 10, 63636370, doi:10.5194/acp-10-6363-2010, 2010.

Chen, L.-W. A., Doddridge, B. G., Dickerson, R. R., Chow, J. C., Mueller, P. K., Quinn, J., and Butler, W. A.: Seasonal variations in elemental carbon aerosol, carbon monoxide, and sulfur dioxide: Implications for sources, Geophys. Res. Lett., 28, 17111714, 2001.

Chen, L.-W. A., Doddridge, B. G., Dickerson, R. R., Chow, J. C., and Henry, R. C.: Origins of fine aerosol mass in the 
Baltimore-Washington corridor: Implications from observation, factor analysis, and ensemble air parcel back trajectories, Atmos. Environ., 36, 4541-4554, 2002.

Chen, L.-W. A., Moosmüller, H., Arnott, W. P., Chow, J. C., Watson, J. G., Susott, R. A., Babbitt, R. E., Wold, C., Lincoln, E., and Hao, W. M.: Particle emissions from laboratory combustion of wildland fuels: In situ optical and mass measurements, Geophys. Res. Lett., 33, 1-4, 2006.

Chen, L.-W. A., Moosmüller, H., Arnott, W. P., Chow, J. C., Watson, J. G., Susott, R. A., Babbitt, R. E., Wold, C. E., Lincoln, E. N., and Hao, W. M.: Emissions from laboratory combustion of wildland fuels: Emission factors and source profiles, Environ. Sci. Technol., 41, 4317-4325, 2007a.

Chen, L.-W. A., Watson, J. G., Chow, J. C., and Magliano, K. L.: Quantifying $\mathrm{PM}_{2.5}$ source contributions for the San Joaquin Valley with multivariate receptor models, Environ. Sci. Technol., 41, 2818-2826, 2007b.

Chen, L.-W. A., Verburg, P., Shackelford, A., Zhu, D., Susfalk, R., Chow, J. C., and Watson, J. G.: Moisture effects on carbon and nitrogen emission from burning of wildland biomass, Atmos. Chem. Phys., 10, 6617-6625, doi:10.5194/acp-10-66172010, 2010a.

Chen, L.-W. A., Watson, J. G., Chow, J. C., DuBois, D. W., and Herschberger, L.: Chemical mass balance source apportionment for combined $\mathrm{PM}_{2.5}$ measurements from U.S. non-urban and urban long-term networks, Atmos. Environ., 44, 4908-4918, $2010 \mathrm{~b}$.

Chen, L.-W. A., Tropp, R. J., Li, W.-W., Zhu, D. Z., Chow, J. C., Watson, J. G., and Zielinska, B.: Aerosol and air toxics exposure in El Paso, Texas: A pilot study, AAQR, 12, 169-189, 2012a.

Chen, L.-W. A., Chow, J. C., Watson, J. G., and Schichtel, B. A.: Consistency of long-term elemental carbon trends from thermal and optical measurements in the IMPROVE network, Atmos. Meas. Tech., 5, 2329-2338, doi:10.5194/amt-5-2329-2012, 2012b.

Chow, J. C.: 2001 Critical review discussion - Diesel engines: Environmental impact and control, J. Air Waste Manage., 51, 12581270, 2001.

Chow, J. C. and Watson, J. G.: Review of $\mathrm{PM}_{2.5}$ and $\mathrm{PM}_{10}$ apportionment for fossil fuel combustion and other sources by the chemical mass balance receptor model, Energ. Fuel., 16, 222260, 2002

Chow, J. C. and Watson, J. G.: Chemical analyses of particle filter deposits, in: Aerosols Handbook: Measurement, Dosimetry, and Health Effects, edited by: Ruzer, L. and Harley, N. H., 179-204, 2012

Chow, J. C., Watson, J. G., Pritchett, L. C., Pierson, W. R., Frazier, C. A., and Purcell, R. G.: The DRI Thermal/Optical Reflectance carbon analysis system: Description, evaluation and applications in U.S. air quality studies, Atmos. Environ., 27A, 1185-1201, 1993.

Chow, J. C., Watson, J. G., Houck, J. E., Pritchett, L. C., Rogers, C. F., Frazier, C. A., Egami, R. T., and Ball, B. M.: A laboratory resuspension chamber to measure fugitive dust size distributions and chemical compositions, Atmos. Environ., 28, 34633481, 1994.

Chow, J. C., Watson, J. G., Chen, L.-W. A., Paredes-Miranda, G., Chang, M.-C. O., Trimble, D., Fung, K. K., Zhang, H., and Zhen Yu, J.: Refining temperature measures in thermal/optical carbon analysis, Atmos. Chem. Phys., 5, 2961-2972, doi:10.5194/acp-
5-2961-2005, 2005.

Chow, J. C., Chen, L.-W. A., Watson, J. G., Lowenthal, D. H., Magliano, K. L., Turkiewicz, K., and Lehrman, D. E.: PM 2.5 chemical composition and spatiotemporal variability during the California Regional $\mathrm{PM}_{10} / \mathrm{PM}_{2.5}$ Air Quality Study (CRPAQS), J. Geophys. Res.-Atmos., 111, 1-17, 2006.

Chow, J. C., Watson, J. G., Chen, L.-W. A., Chang, M. C. O., Robinson, N. F., Trimble, D. L., and Kohl, S. D.: The IMPROVE_A temperature protocol for thermal/optical carbon analysis: Maintaining consistency with a long-term database, J. Air Waste Manage., 57, 1014-1023, 2007a.

Chow, J. C., Watson, J. G., Feldman, H. J., Nolan, J., Wallerstein, B. R., Hidy, G. M., Lioy, P. J., McKee, H. C., Mobley, J. D., Bauges, K., and Bachmann, J. D.: 2007 Critical review discussion - Will the circle be unbroken: A history of the U.S. National Ambient Air Quality Standards, J. Air Waste Manage., 57, 1151-1163, 2007b.

Chow, J. C., Watson, J. G., Lowenthal, D. H., Chen, L. W. A., Zielinska, B., Mazzoleni, L. R., and Magliano, K. L.: Evaluation of organic markers for chemical mass balance source apportionment at the Fresno Supersite, Atmos. Chem. Phys., 7, 17411754, doi:10.5194/acp-7-1741-2007, 2007c.

Chow, J. C., Yu, J. Z., Watson, J. G., Ho, S. S. H., Bohannan, T. L., Hays, M. D., and Fung, K. K.: The application of thermal methods for determining chemical composition of carbonaceous aerosols: A Review, J. Environ. Sci. Heal. A, 42, 1521-1541, 2007d.

Chow, J. C., Watson, J. G., Lowenthal, D. H., Park, K., Doraiswamy, P., Bowers, K., and Bode, R.: Continuous and filter-based measurements of $\mathrm{PM}_{2.5}$ nitrate and sulfate at the Fresno Supersite, Environ. Mon. Assess., 144, 179-189, 2008.

Chow, J. C., Watson, J. G., Chen, L.-W. A., Rice, J., and Frank, N. H.: Quantification of $\mathrm{PM}_{2.5}$ organic carbon sampling artifacts in US networks, Atmos. Chem. Phys., 10, 5223-5239, doi:10.5194/acp-10-5223-2010, 2010.

Chow, J. C., Watson, J. G., Robles, J., Wang, X. L., Chen, L.-W. A., Trimble, D. L., Kohl, S. D., Tropp, R. J., and Fung, K. K.: Quality assurance and quality control for thermal/optical analysis of aerosol samples for organic and elemental carbon, Anal. Bioanal. Chem., 401, 3141-3152, 2011.

Chu, S. H.: $\mathrm{PM}_{2.5}$ episodes as observed in the speciation trends network, Atmos. Environ., 38, 5237-5246, 2004

El-Zanan, H. S., Lowenthal, D. H., Zielinska, B., Chow, J. C., and Kumar, N. K.: Determination of the organic aerosol mass to organic carbon ratio in IMPROVE samples, Chemosphere, 60, 485-496, 2005.

Engling, G., Carrico, C. M., Kreldenweis, S. M., Collett Jr., J. L., Day, D. E., Malm, W. C., Lincoln, E., Hao, W. M., Iinuma, Y., and Herrmann, H.: Determination of levoglucosan in biomass combustion aerosol by high-performance anion-exchange chromatography with pulsed amperometric detection, Atmos. Environ., 40, S299-S311, 2006.

Fernando, H. J. S.: Fluid dynamics of urban atmospheres in complex terrain, Annu. Rev. Fluid Mech., 42, 365-389, 2010.

Fitz, D. R., Chow, J. C., and Zielinska, B.: Development of a gas and particulate matter organic speciation profile database, prepared for Draft Final Report June 2003, Prepared fro San Joaquin Valleywide Air Pollution Study Agency; California Regional $\mathrm{PM}_{10} / \mathrm{PM}_{2.5}$ Air Quality Study by Desert Research Institute, 
Reno, NV, 2003.

Flanagan, J. B., Jayanty, R. K. M., Rickman Jr., E. E., and Peterson, M. R.: $\mathrm{PM}_{2.5}$ Speciation Trends Network: Evaluation of wholesystem uncertainties using data from sites with collocated samplers, J. Air Waste Manage., 56, 492-499, 2006.

Fraser, M. P. and Lakshmanan, K.: Using levoglucosan as a molecular marker for the long-range transport of biomass combustion aerosols, Environ. Sci. Technol., 34, 4560-4564, 2000.

Fraser, M. P., Yue, Z. W., and Buzcu, B.: Source apportionment of fine particulate matter in Houston,TX, using organic molecular markers, Atmos. Environ., 37, 2117-2123, 2003.

Fujita, E. M., Campbell, D. E., Arnott, W. P., Chow, J. C., and Zielinska, B.: Evaluations of the chemical mass balance method for determining contributions of gasoline and diesel exhaust to ambient carbonaceous aerosols, J. Air Waste Manage., 57, 721740, 2007a.

Fujita, E. M., Zielinska, B., Campbell, D. E., Arnott, W. P., Sagebiel, J. C., Mazzoleni, L. R., Chow, J. C., Gabele, P. A., Crews, W., Snow, R., Clark, N. N., Wayne, W. S., and Lawson, D. R.: Variations in speciated emissions from spark-ignition and compression-ignition motor vehicles in California's south coast air basin, J. Air Waste Manage., 57, 705-720, 2007b.

Green, M. C., Chen, L.-W. A., DuBois, D. W., and Molenar, J. V.: $\mathrm{PM}_{2.5}$ and visibility in the Lake Tahoe Basin: Chemical characterization, trends, and source apportionment, J. Air Waste Manage., 62, 953-965, 2012a.

Green, M. C., Chow, J. C., Chang, M.-C. O., Chen, L.-W. A., Kuhns, H. D., and Etyemezian, V. R.: Source apportionment of atmospheric particulate carbon in Las Vegas, Nevada, USA, Particuology, in press, 2012b.

Gyawali, M., Arnott, W. P., Zaveri, R. A., Song, C., Moosmüller, H., Liu, L., Mishchenko, M. I., Chen, L.-W. A., Green, M. C., Watson, J. G., and Chow, J. C.: Photoacoustic optical properties at UV, VIS, and near IR wavelengths for laboratory generated and winter time ambient urban aerosols, Atmos. Chem. Phys., 12, 2587-2601, doi:10.5194/acp-12-2587-2012, 2012.

Held, T., Ying, Q., Kleeman, M. J., Schauer, J. J., and Fraser, M. P.: A comparison of the UCD/CIT air quality model and the CMB source-receptor model for primary airborne particulate matter, Atmos. Environ., 39, 2281-2297, 2005.

Ho, S. S. H. and Yu, J. Z.: In-injection port thermal desorption and subsequent gas chromatography-mass spectrometric analysis of polycyclic aromatic hydrocarbons and $n$-alkanes in atmospheric aerosol samples, J. Chromatogr. A, 1059, 121-129, 2004.

Ho, S. S. H., Yu, J. Z., Chow, J. C., Zielinska, B., Watson, J. G., Sit, E. H. L., and Schauer, J. J.: Evaluation of an in-injection port thermal desorption-gas chromatography/mass spectrometry method for analysis of non-polar organic compounds in ambient aerosol samples, J. Chromatogr. A, 1200, 217-227, 2008.

Ho, S. S. H., Chow, J. C., Watson, J. G., Ng, L. P. T., Kwok, Y., Ho, K. F., and Cao, J. J.: Precautions for in-injection port thermal desorption-gas chromatography/mass spectrometry (TDGC/MS) applied to aerosol filter samples, Atmos. Environ., 45, 1491-1496, 2011.

Huber, P. J.: Robust Statistics, John Wiley and Sons, Inc., New York, NY, 1981.

Kim, B. M. and Henry, R. C.: Diagnostics for determining influential species in the chemical mass balance receptor model, J. Air Waste Manage., 49, 1449-1455, 1999.
Kirchstetter, T. W., Novakov, T., and Hobbs, P. V.: Evidence that the spectral dependence of light absorption by aerosols is affected by organic carbon, J. Geophys. Res.-Atmos., 109, D21208, doi:10.1029/2004JD004999, 2004.

Kuhns, H. D., Chang, M.-C. O., Chow, J. C., Etyemezian, V., Chen, L.-W. A., Nussbaum, N. J., Nathagoundenpalayam, S. K., Trimble, T. C., Kohl, S. D., MacLaren, M., Abu-Allaban, M., Gillies, J. A., and Gertler, A. W.: DRI Lake Tahoe Source Characterization Study, prepared for California Air Resources Board, Sacramento, CA by Desert Research Institute, Reno, NV, 2004.

Ling-Barnes, Y.: Washoe County, Nevada, 2008 periodic emissions inventory, prepared by Washoe County Health District Air Quality Divison, Reno, NV, 2010.

Lloyd, A. C. and Cackette, T. A.: Critical review - Diesel engines: Environmental impact and control, J. Air Waste Manage., 51, 809-847, 2001.

Malm, W. C., Sisler, J. F., Huffman, D., Eldred, R. A., and Cahill, T. A.: Spatial and seasonal trends in particle concentration and optical extinction in the United States, J. Geophys. Res., 99, 13471370, 1994.

Mendoza, L. and Inouye, D.: Washoe County, Nevada, air quality trends (2001-2010), prepared by Washoe County Health District Air Quality Divison, Reno, NV, 2011.

Moosmüller, H., Chakrabarty, R. K., and Arnott, W. P.: Aerosol light absorption and its measurement: A review, J. Quant. Spectrosc. Rad., 110, 844-878, 2009.

Nam, E., Kishan, S., Baldauf, R. W., Fulper, C. R., Sabisch, M., and Warila, J.: Temperature effects on particulate matter emissions from light-duty, gasoline-powered motor vehicles, Environ. Sci. Technol., 44, 4672-4677, 2010.

Nussbaum, N. J., Zhu, D., Kuhns, H. D., Mazzoleni, C., Chang, M.C. O., Moosmüller, H., and Watson, J. G.: The In-Plume Emissions Test-Stand: A novel instrument platform for the real-time characterization of combustion emissions, J. Air Waste Manage., 59, 1437-1445, 2009.

Ramdahl, T.: Retene-A molecular marker of wood combustion in ambient air, Nature, 306, 580-582, 1983.

Rinehart, L. R., Fujita, E. M., Chow, J. C., Magliano, K. L., and Zielinska, B.: Spatial distribution of $\mathrm{PM}_{2.5}$ associated organic compounds in central California, Atmos. Environ., 40, 290-303, 2006.

Russell, L. M.: Aerosol organic-mass-to-organic-carbon ratio measurements, Environ. Sci. Technol., 37, 2982-2987, 2003.

Silcox, G. D., Kelly, K. E., Crosman, E. T., Whiteman, C. D., and Allen, B. L.: Wintertime $\mathrm{PM}_{2.5}$ concentrations during persistent, multi-day cold-air pools in a mountain valley, Atmos. Environ., 46, 17-24, 2012.

Speer, R. E., Edney, E. O., and Kleindienst, T. E.: Impact of organic compounds on the concentrations of liquid water in ambient $\mathrm{PM}_{2.5}$, J. Aerosol Sci., 34, 63-77, 2003.

Tai, A. P. K., Mickley, L. J., and Jacob, D. J.: Correlations between fine particulate matter $\left(\mathrm{PM}_{2.5}\right)$ and meteorological variables in the United States: Implications for the sensitivity of $\mathrm{PM}_{2.5}$ to climate change, Atmos. Environ., 44, 3976-3984, 2010.

USEPA: Air quality criteria for particulate matter, prepared by U.S. Environmental Protection Agency, Research Triangle Park, NC, 2004.

USEPA: 40 CFR Parts 50, 51, 52, 53, and 58-National ambient air quality standards for particulate matter: Proposed rule, Federal 
Register, 77, 38890-39055, 2012.

Watson, J. G.: Chemical element balance receptor model methodology for assessing the sources of fine and total suspended particulate matter in Portland, Oregon, 1979.

Watson, J. G. and Chow, J. C.: A wintertime $\mathrm{PM}_{2.5}$ episode at the Fresno, CA, supersite, Atmos. Environ., 36, 465-475, 2002.

Watson, J. G. and Chow, J. C.: Source apportionment, in: The Encyclopedia of Environmetrics, edited by: El-Shaarwi, A. H. and Piegorsch, W. W., John Wiley \& Sons, in press, 2012.

Watson, J. G., Cooper, J. A., and Huntzicker, J. J.: The effective variance weighting for least squares calculations applied to the mass balance receptor model, Atmos. Environ., 18, 1347-1355, 1984.

Watson, J. G., Chow, J. C., Lurmann, F. W., and Musarra, S.: Ammonium nitrate, nitric acid, and ammonia equilibrium in wintertime Phoenix, Arizona, J. Air Waste Manage., 44, 405-412, 1994.

Watson, J. G., Chen, L.-W. A., Chow, J. C., Lowenthal, D. H., and Doraiswamy, P.: Source apportionment: Findings from the U.S. Supersite Program, J. Air Waste Manage., 58, 265-288, 2008.

Watson, J. G., Chow, J. C., Chen, L.-W. A., and Frank, N. H.: Methods to assess carbonaceous aerosol sampling artifacts for IMPROVE and other long-term networks, J. Air Waste Manage., 59, 898-911, 2009.
Watson, J. G., Chow, J. C., Chen, L.-W. A., Green, M. C., and Kohl, S. D.: Wintertime $\mathrm{PM}_{2.5}$ source contributions in Reno, NV, prepared for Reno, NV, Washoe County Health District, Air Quality Division by Desert Research Institute, Reno, NV, 2011.

Weilenmann, M., Favez, J. Y., and Alvarez, R.: Cold-start emissions of modern passenger cars at different low ambient temperatures and their evolution over vehicle legislation categories, Atmos. Environ., 43, 2419-2429, 2009.

West, J. J., Ansari, A. S., and Pandis, S. N.: Marginal PM 2.5 : Nonlinear aerosol mass response to sulfate reductions in the eastern United States, J. Air Waste Manage., 49, 1415-1424, 1999.

Yang, H., Li, Q. F., and Yu, J. Z.: Comparison of two methods for the determination of water-soluble organic carbon in atmospheric particles, Atmos. Environ., 37, 865-870, 2003.

Zhu, D. Z., Nussbaum, N. J., Kuhns, H. D., Chang, M. C. O., Sodeman, D., Uppapalli, S., Moosmüller, H., Chow, J. C., and Watson, J. G.: In-Plume Emission Test Stand 2: Emission factors for 10-to 100-kW US military generators, J. Air Waste Manage., 59, 1446-1457, 2009.

Zielinska, B., Campbell, D. E., Lawson, D. R., Ireson, R. G., Weaver, C. S., Hesterberg, T. W., Larson, T., Davey, M., and Liu, L. J. S.: Detailed characterization and profiles of crankcase and diesel particulate matter exhaust emissions using speciated organics, Environ. Sci. Technol., 42, 5661-5666, 2008. 